\section{MARSH HAWK ATTEMPTS TO SALVAGE A DEAD COOT}

by John B. Millar,

Canadian Wildlife Service, Saskatoon

On September 30, 1963, while making a waterfowl count at a slough southeast of Swift Current, Saskatchewan, I noted a Marsh Hawk (Circus hudsonius), likely an adult female, judging from its dark color, cruising low along the shore. A number of dead ducks and coots were floating on the slough, apparently having been shot. The hawk flew to the carcass of an American Coot (Fulica americana) which was floating on a matted bed of spikerush (Eleocharis palustris) and began repeated but unsuccessful attempts to drag the bird to shore. On each attempt it gripped some part of the carcass (either the head, trunk, or wing) with its feet and lunged upward repeatedly in an effort to become airborne. After several such efforts it would settle back on the coot to rest, occasionally picking at it but making no serious attempt to feed. Under the weight of the hawk the coot would gradually sink through the vegetation until the hawk, on extended legs, was often breast deep in water. At this point it would take a fresh grip and resume its efforts to get the carcass airborne.

The entire procedure was repeated several times within a period of 12 minutes, and during that time the hawk succeeded in moving the coot about three feet toward shore. At this point the carcass slipped from the hawk's grasp, whereupon the bird arose and dipped to water level two or three times without apparently touching the coot. The hawk then flew to the shore where it rested for perhaps two minutes before returning to try once more to lift the coot. After this it returned to the shore, came out a third time but made only a halfhearted attempt, then cruised about for a minute or so and returned to touch the water briefly at the approximate location of the dead bird before departing.

After the Marsh Hawk's departure I attempted unsuccessfully to find the coot. The nature of the disappearance of the coot and the final behaviour of the hawk suggests that the bird had succeeded in moving the carcass to the edge of the spikerush bed where it was no longer supported by the vegetation and simply sank to the bottom of the pond.

Considering that an adult coot may range in weight from 533 to 829 grams (Gullion, G. W. 1952. Sex and age determination in the American Coot. $J$. Wildl. Mgmt. 16:191-197) and that the average weight of a female Marsh Hawk is in the order of 570 grams, it is evident that the hawk was struggling' with a dead weight approximately equal to its own. A further example of this sort of behaviour is given by M. C. Hammond (1948. Marsh Hawk kills Baldpate. Auk., 65:297-298), who describes the unsuccessful efforts of a Marsh Hawk to drag a 1,003-gram American Widgeon (Mareca americana), which it had killed, to shore.

\section{REGARDING WINTER RECORDS OF THE SNOWY OWL}

by Bernard Haysom, Regina

For some time now I have been trying to determine the winter range of the Snowy Owl in Saskatchewan. The excellent response to my requests in the Blue Jay for records has given me much to work on. Generally, the Snowy Owl appears to occur as a winter visitor throughout the province, but it is most common in the southern third of the province. However, in the area bounded on the north by highways No. 1 and No. 16, on the west by No. 4, and on the east and south by the borders, the Snowy Owl has been reported at only five points (Oxbow, Carnduff, Francis, Gravelbourg, and Kincaid). In the north, sightings generally cease at a line through Nipawin, Prince Albert, and North Battleford, but we do have reports from Paddockwood, Birch Lake, Eldorado, Reindeer Lake, and Pelican Narrows. These records suggest that Snowies also occur in winter across the boreal forest region.

I would like to make a special request for sightings in the two areas in which there are few records, namely, the northern two-thirds of the province, and the extreme southern region, from south of Swift Current and Regina to Estevan. Of course, reports of sightings in any area would be welcome. Please send records to me at 15 Crerar Street, Regina. 